\title{
"This imperfect part of truth:"1 The Godwits Fly, Childhood Memory and Fiction
}

\author{
ELIZABETH TOWL
}

Having completed the final version of The Godwits Fly and sent it away to be published, Iris Wilkinson (Robin Hyde) $)^{2}$ wrote to John A. Lee that she had finished "the camouflaged autobiographical novel and posted it-It will have to go as fiction and it's only twenty-one years of a life [...] But I've got a good deal into it that I really wanted to." ${ }^{3}$ The Godwits Fly had its origins in the therapeutic autobiographical writing that she was encouraged to undertake at the Auckland Mental Hospital, where she was a voluntary patient from June 1933 until early 1937. She recorded in her journal her decision to write a "faintly autobiographical novel called "The Godwits Fly"' on March $2^{\text {nd }}, 1935 .{ }^{4}$ Over the two years and several drafts that intercede between this journal entry and her letter to John A. Lee, the novel became rather more than "faintly autobiographical."

Hyde's characterisation of the finished novel to Lee as a "camouflaged autobiographical novel" that "will have to go as fiction" draws attention to the tension between the lived experience upon which the novel is based and the reworking of that experience into fiction. Writing again to Lee more than a year later, Iris said that The Godwits Fly was "not a novel, but I had to say it was - the only lies of major importance are camouflage for other people." 6 All autobiographies - even those that are not camouflaged as novels - are constructions; Brunner explains that "Autobiography is not and cannot be a way of simply signifying or referring to a 'life as lived' [... A] life is created or constructed by the act of autobiography."7 The autobiography that Iris has written as part of her psychiatric treatment in 1934 (the "1934 Autobiography") incorporates comments about its context and its status as an overtly constructed narrative throughout. ${ }^{8}$ The text refers to the other inmates of the hospital, to the restrictions that Hyde places on the text or decisions that she has had to make about what she will or will not, can or cannot explain as she writes it. It is also clear about its primary audience, "you"-Dr Gilbert Tothill, her psychiatrist. ${ }^{9}$ Hyde had considered publishing this autobiography. In a letter to John Schroder, she writes "I will never again write anything more sincere or better-well the person I wrote it for is proud of it \& wants it to be published." 10 In her next letter, she calls it a "prose book, it is not a novel but a sliding picture of the days, which I do care for $[\ldots . \mathrm{M}] \mathrm{y}$ English Doctor $[\ldots]$ thinks it is dangerous and not brilliantly written, but he understands it and loves it all the same. Whether it goes to the publisher is a question swinging in the balance." 11 In the end, the autobiography itself was not published until 2011, when Mary Edmond-Paul edited it as part of Your Unselfish Kindness: Robin Hyde's Autobiographical Writings, but Sandbrook suggests that The Godwits Fly arose from "a desire to recast [the material from the autobiography] into an immediately publishable form." 12

Hyde's comments about her "camouflaged autobiographical novel" to John A. Lee are the comments of one author to another whose work she had hoped to emulate. Hyde reviewed Lee's Children of the Poor in January 1935, and her "review admired a method of writing, which produced the effect that [she] herself was striving to achieve." "13 Initially published anonymously, Lee's novel uses details of his own childhood to construct the first-person account of Albany Porcello, through which he is able to draw attention to the plight of the poor in Depression-era New Zealand. The scandal that broke out once Lee revealed his authorship of the novel and the autobiographical basis for the story may have been a warning for Hyde, too, and may have contributed to her impulse towards camouflage. Anna Rutherford explains that by the time that Lee's authorship of Children of the Poor was revealed, he "was a Labour member of parliament. The conservative New Zealand public found it offensive that one of 
their leading figures and representatives should admit to a delinquent past, a prostitute sister, a drunken grandmother, and a childhood of squalor and poverty." "The published version of The Godwits Fly includes details which the New Zealand public would have found very challenging had their autobiographical basis been emphasised, such as the conception outside wedlock and the stillbirth of Iris's first son, her first nervous breakdown and a series of suicide attempts. At the time of writing both the autobiography and The Godwits Fly she was staying (albeit voluntarily) at a psychiatric facility, having lost her job as a journalist and attempting a public suicide by jumping from a wharf in the very centre of Auckland. ${ }^{15}$ She must have been aware of the potential dangers for her career of Eliza Hannay's experience being too nearly associated with her own.

It is the extent, the method and the effect of the camouflage in The Godwits Fly that lies at the heart of this article. The slippery relationship between the concepts "camouflage" "autobiography" and "novel" which Hyde invokes when describing the final product to Lee suggest a series of questions that ought to be asked of any fictionalised autobiography, and particularly any fictionalised autobiography that takes in the author's childhood. When you can keep or change anything of the life you have lived, what do you keep, and what do you change? When your family become fictional characters, and you can make them act, think, and behave in any way, how do you characterise them? Finally, how does one, as an adult who has both the benefit of hindsight and the benefits (or otherwise) of an adult's perspective and understanding, represent the perspective one had on those one loved as a child?

In attempting to make sense of these questions in Hyde's case, we are lucky to have access to a great deal of documentary evidence. In 2009, Derek Challis, Iris's son, deposited his collection of papers relating to his mother's life and writing in the Alexander Turnbull Library. This tremendously rich collection includes most of the draft material of The Godwits Fly, the remainder being held at Auckland University Library. The draft material and the published version demonstrate three stages in the development of the novel. Most of the draft usually designated the "first version" is held in the Turnbull (MS-Papers-9110-135) and is completed by a 38-page fragment in the University of Auckland Library (MSS and Archives B-12b, folder 5). ${ }^{16}$ Typescript drafts of sections of the novel and hand-written material in a series of exercise books dating to mid-to-late 1936 represent an intermediate stage in Hyde's redrafting of the novel. The published version was completed in March 1937 and published by Hurst and Blackett in 1938.

We have access to a significant amount of information about Iris's life, too, because Derek Challis' Turnbull material includes folders and folders of papers-correspondence, notes, medical records. Challis and Gloria Rawlinson used this material in their biography of Hyde, The Book of Iris, which was published in 2002. Finally, we have access to two editions of Hyde's more traditionally autobiographical writings. A Home in this World, the memoir written by Hyde in early 1937 was edited and published by Derek Challis in 1984; Mary Edmond-Paul has recently edited the 1935 and 1936 journals together with the 1934 Autobiography in Your Unselfish Kindness.

This paper uses all of these sources-fictional and fictionalised, autobiographical, biographical and documentary - to consider the character of Augusta Hannay, Hyde's fictionalised version of her mother, Nelly Wilkinson. Sandbrook has argued that in The Godwits Fly "Eliza's parents and the other minor characters are seen less as reliable portraits of Hyde's family and friends than as fictional embodiments of Eliza's central psychological conflict." 17 He explains in depth how the characterisation of John and Augusta Hannay in particular achieves this function. ${ }^{18}$ Reacting against earlier criticisms of Hyde's writing for its naivety and supposed overreliance on her own lived experience, ${ }^{19}$ Sandbrook shows how these characters demonstrate Hyde's care and skill, and how her treatment of them contributes to the thematic unity of the published version of the novel. My focus here is slightly different, 
emphasising and reclaiming the autobiographical detail as further evidence of Hyde's care and skill. In the remainder of this paper, I will track the changes and continuities in Hyde's characterisation of Augusta across the various drafts. Freed from the "autobiographical pact" by the liberties of fiction, Hyde need not attempt to represent "reliable portraits" of any of her loved ones, but I will argue that the available documentary and intertextual evidence demonstrates that Augusta Hannay becomes more and more like Nelly Wilkinson by the final version. ${ }^{20}$ This impression is borne out in the autobiographies and journals, the documentary sources and the autobiographical poems that Hyde wrote near the end of her short life. These sources also support my suggestion that Hyde's representation of a complex relationship between mother and daughter evolves through the drafts and is preserved in the final, published version of The Godwits Fly.

The different versions of Augusta that appear through the process of writing and redrafting The Godwits Fly demonstrate both a sympathy for the social and economic situation of women in general and a growing understanding of and sympathy for Nelly's situation in particular. Augusta's characterisation is underpinned by certain characteristics that are drawn from Nelly: from the very beginning, Augusta is proud, strong, determined, and entirely loyal to the British Empire and the Church of England. Augusta and Nelly are the "first of the godwits," the children of the colonies who fly north, and for whom "North was mostly England, or a detour to England." ${ }^{21}$ But Augusta and Nelly are also both thwarted godwits: their journeys to England are interrupted by marriage to John/Eddie in South Africa, by children and by domestic responsibilities.

Although Augusta's character is consistent across the various drafts, the conditions within which she operates change significantly between the first and later versions. In the first version, she is a war widow with gentle hands, who protects her children from as much of the reality of their poverty as she can. We learn about her history mainly from the stories she tells Eliza in the twilight, while Eliza brushes out her long auburn hair for her, a detail which the 1934 Autobiography confirms is carried over from Iris and Nelly's relationship. ${ }^{22}$ This history includes the vibrant description of Augusta's youth in Australia, and her stopping on her way to England in Cape Town to earn money as a nurse, where she finds herself pursued by an amorous, injured young cavalry officer. Of their consequent marriage, Eliza notes that " $[t]$ here seems to be singularly little a nurse can do with a disabled soldier who attaches himself doggedly to her, beyond marrying him. The obvious course, however, is not always the wise one." ${ }^{23}$ Fate intervenes, but does not necessarily improve Augusta's circumstances: by page 22 , the war has made her a widow and also a solo mother.

In this first version, therefore, Augusta represents a form of female economic marginalisation that was prevalent in a society emerging from its first world war. As a woman of her class and generation, her financial position had never been strong and had hampered her attempts to leave home and get to England: "To be utterly without money, without the means of making surplus money, as the women of her generation had been, meant moving with nightmare slowness." 24 Much of the sympathy for Augusta in the first version is founded upon her introduction as a strong, determined young woman who "never saw England, yet to the end of her life [...] was going there," but who is trapped first by marriage and then by widowhood and solo-motherhood. ${ }^{25}$ The Augusta of the later drafts and Nelly herself had their own economic and social struggles with which to contend, but they were not struggles exacerbated by the loss of a husband.

In the intermediate drafts and final version, John survives the war. The trials with which Nelly had to contend and the rows to which Iris's parents' relationship was subject come along with him. John is impulsive, idealistic and impractical. He buys the children little gifts and puts coats on their beds to keep them warm, but his temper is frightening: 
His voice got too big, filling the house like the smoke-djinn that escaped from the bottle. [...] The veins stood out on his forehead, and he swore at God and the British Empire; half the time it was some tiny thing that set him off. He seemed to be two people rolled into one - the thin, brown one who laughed, and the thin, red one who quarrelled. ${ }^{26}$

The parental rows that pepper The Godwits Fly were an important feature of Iris' childhood and their inclusion in the later drafts of the novel is a deliberate step towards a more autobiographical approach. Both autobiographical and documentary sources confirm the severity of the rows and their effect on Iris. The notes taken upon Iris' voluntary admission in June 1933 state that "As a girl she was [...] worried over disagreements between her parents. Her father was liable to 'storms of passion' and eventually her parents separated." 27 In the 1934 Autobiography, Iris notes that

I couldn't stand the voices in the night. My Father was still, not in love with, but in need of my mother: she had begun to hate him. Half-heard arguments over a halfunderstood thing! It was like that idiotic book I half read: just ugliness, so close, whispering so often. And one can't tell one's progenitors "Do shut up." As far as that goes, if they had, the pity that lay beneath my horror would have gone on working. ${ }^{28}$

Reinstating a version of her father, his temper and the problems he caused her mother, Hyde rewrites The Godwits Fly looking back on an unstable parental relationship that affected her well into adulthood.

Underlying these parental rows - both autobiographical and fictional - is a complete mismatch of values. Like Eddie, John is an impulsive and erratic Socialist; Augusta, like Nelly, is a dogged and determined Imperialist, who is very concerned with the family's place in society. She is particular about how the girls dress and behave, and where the family lives. John's taking a house in Newtown - a suburb which "in its half-century of life had contrived to get itself very dirty"29 — without consulting Augusta, for example, struck at the heart of the social gains that she had been working so hard to achieve. Hyde writes that moving down from the hill-suburbs into Newtown "was a blow from which Augusta took years to recover. It used up all her softness, all she had in hand besides fortitude and pride." ${ }^{30}$ It is not the absence of a husband (as in the first version draft) that affects Augusta's economic and social marginalisation; Augusta's key social and financial problems often result from John's actions and his different values.

Augusta's uphill struggle for respectability has its foundations in Nelly's experience. Nelly had worked hard to foster and maintain social respectability on extremely limited resources, and her achievements in household management were apparently widely known and respected. A neighbour recalled in a letter in 1935 that "Never were children looked after better than the little Wilkinsons of Waripori St. The little girls were their mother's one thought and her own desire to see them brought up nice girls was a wish never away from her desire and thoughts." 31 One of the ways in which both the little Wilkinsons and the little Hannays were so well looked after was in the dresses that Nelly and Augusta created for them. Hyde recognises the effort that this work entailed, although the younger versions of herself (both real and fictional) appear not to have done. In her poem "The People," Hyde remembers that her mother's

eyes looked tired

As long as I remember, and her strong mouth sad.

Still she held firmly: when we went for walks

It was I who flagged: you'd never guess what frocks

She made us, while the clean thread broke and broke, 
And I stood pricking at red sateen, or spoke Roughly ${ }^{32}$

In a rare example of direct access to Augusta's thoughts, the final version of The Godwits Fly records her thinking about her struggles for the benefit of her family, expressed in terms of food and the products of her labour at the sewing machine: "Good food for them, though she remembered sitting at table with one egg, and that wasn't for her, though Sandra was coming. And when they were little, her children's frocks were always the prettiest and the best, though now her sight blurred behind her spectacles, and the old sewing-machine broke the thread so often that using it taxed her patience." ${ }^{33}$ Eliza, too, recognises that it was in caring about these things in particular that Augusta expressed her love for her children: "She was too busy, where the children were concerned, for any of them to stand apart and say, 'This is exactly how my mother loves me.' It all came in the form of groceries and little frocks run up on the hand machine, and what you mustn't say or let people say to you if you're to pass muster among decent folk." 34

Part of Nelly's battle to have her family "pass muster among decent folk" was against their innate resistance to her efforts. Augusta faces the same challenges in the novel. As I mentioned above, John takes out a lease on a house without discussing it with Augusta, putting her in the position of either paying double rent (which is impossible) or moving to an area that she cannot stand. ${ }^{35}$ Eliza tends not to recognise the social repercussions and potential dangers of doing things like fraternising with the drunken men at the park. ${ }^{36}$ Sandra "stalk[s] quite naked across the Back Yard" to the copper for her bath, observed by a group of neighbourhood boys. ${ }^{37}$ Only Carly participates willingly in the programme of social improvement that Augusta had instituted; she "liked doing things she was told" and would try to modify her younger sisters' behaviour. ${ }^{38}$ Augusta's attempts to control her daughters' behaviour is not as pronounced towards Kitch, the youngest child and only son. ${ }^{39}$ As a male, his behaviour is not subject to the same public scrutiny. Unlike his older sisters, he need not worry about the social and financial repercussions of things like unplanned pregnancy. For young women, Eliza explains in the first version draft, "there are the eternal dragging considerations of possible or prospective maternity, about which the whole of senior femininity keeps up a constant discouraging and mysterious murmur. Outside marriage there are, of course, all the humiliations and punishments of public opinion, which can go quite as far as starvation or ostracism of the culprit." ${ }^{\prime 4}$ For both Iris and Eliza, pregnancy outside of wedlock was not just a worry - it became a reality.

According to the 1934 Autobiography, Nelly's reaction to news of Iris's pregnancywhich Iris had told her was the result of an encounter with a man who "was drunk, and he didn't know what he was doing!"-was to say, "coldly, 'You drunken harlot." 41 Iris's pregnancy and her refusal simply to marry the baby's father struck right at the heart of Nelly's values. Nelly fixated on the idea of the drunken encounter: "A child of drink... I wonder what it will be like. I've never seen one." But Iris immediately undercuts Nelly's coldness, saying "But that's not the truest memory of her at this time. Because one sentence happens, it doesn't say that any other brave and loyal thing doesn't and curiously enough, I think it was after I'd beaten down her marriage-at-any-price idea, that our real comradeship began. It has always lasted." ${ }^{2}$ Although Nelly had struggled with Iris' pregnancy, she went to Sydney to look after Iris and bring her home after the baby was stillborn. ${ }^{43}$

None of the versions of The Godwits Fly suggest that Augusta knows about the pregnancy prior to Eliza's leaving for Sydney. In fact, it is not at all clear in the first version that Eliza is pregnant until she gives birth. In the later versions the pregnancy is much more clearly articulated, but the real reason for Eliza's sudden trip to Sydney seems to have been kept from everyone except the baby's father and Simone, Eliza's best friend. In the published version, 
Augusta stands down on the wharf to see Eliza off among the other Hannays: "Eliza knew that Augusta's shoes were hurting her, but that she had put on her best because Eliza's going to Sydney, where she might really strike it rich, was a kind of festive event." 44 There is no suggestion of scandal here, the emphasis remaining on Eliza's cover story.

The first and final versions of the novel include Eliza's nervous breakdown after the death of her baby and her return to New Zealand - the interim draft does not. In the first version, the focus of the account of the breakdown is social; because Eliza is not particularly fussed by what her community thinks of her, it is the repercussions for Augusta that predominate. Eliza's pregnancy and its outcome are kept secret, but Augusta, we are told, "knew: and knowing, suffered, hated her knowledge, half loved, half hated me, never for one minute understood." ${ }^{45}$ Eliza interprets this deep lack of understanding and the internal conflict caused by a loved child who takes a path that runs contrary to one's own values, noting that Augusta "would be happy neither if I stayed with her nor if I went away again. [...] She had grown acclimatized to the social touch, sound and smell. Once that happens, nothing is too much to buy them back again." ${ }^{46}$ Eliza also contextualises the importance of society and community to Augusta in terms of her history:

At best of times, our family had had its difficulties in finding a place for itself in any sort of society. For a while, one foot in a sharp-tongued, sharp-sworded, penniless gentility: for a brief time, after my Father died, a prospect of sinking below the breadline and decency line altogether, for mere want of money. Then, because of my Mother's steady hand and steady heart, the gradual building up of a home neither poor nor in the lowest degree affluent, neither degraded nor at all comfortable. Never enough coal for the fire in winter, but on the other hand, always a few books on the shelf, a few flowers in the garden, a change of linen." 47

The damage that open knowledge of Eliza's secret could do to Augusta's hard-won respectability, Eliza recognises "would take years as long as centuries to restore." 48

In the final version, on the other hand, Eliza's breakdown and Augusta's response is entirely a private affair. In a series of events very similar in many ways to those recounted in the 1934 Autobiography, ${ }^{49}$ Eliza makes a trip to see the father of her dead baby and finds him married. She takes a lot of drugs as part of an apparent suicide attempt ${ }^{50}$ she is admitted to hospital and her mother comes to get her and take her home. Augusta is very gentle, repeating "Well, old dear"-nothing more. ${ }^{51}$ Her physical appearance speaks to her worry about Eliza: "Her face looked seamed and ashen-grey, she was wearing horrible fabric gloves that had burst their seams, or came undone at their tops." 52 The state of her gloves, considering how much clothes matter to her, suggests her concern-she has not taken her usual care to look respectable. In this last version of the novel, when Eliza needs her, it seems that she drops everything to be there - no questions, no recriminations, not a breath of worry about what people might think, just "Well, old dear."

The Augusta that emerges from the introduction of episodes like this one is a testament to the version of her mother that Hyde wanted to fashion out of autobiography and fiction. As I noted above, Iris wrote of her mother's reaction to her pregnancy, "Because one sentence happens, it doesn't say that any other brave and loyal thing doesn't." In A Home in this World, Iris records some very unkind comments from Nelly, but always with an explanation; she also records the "brave and loyal" things which provide the wider context for their relationship. When she returns to Wellington after Derek's birth, she says "I found myself hated: there is no other word." 53 She remembers that Nelly said to her "You look about thirty. Fat and coarse. I can hardly believe that you're my daughter." 54 But she remembers her father stopping her "on the stairs, shambling and timid. 'Don't take too much notice of what your Mother says, old girl. She doesn't mean it. She's got worries." It is the "worries," not Iris herself, that cause 
Nelly's unkindness, and those "worries, nesting in the brain, must engender caution." 55 Later in the same memoir, Hyde would write that Nelly "hated $u s$, for the sake of the brilliant, laughing, courageous children we might have been; she prodded us, unsuccessfully, to make us tread in the paths they would have taken." 56 "Hate" is a strong word, and one that is particularly jarring as a description of the feelings of one's own mother, and it is a concept to which Hyde returns in her characterisation of her mother around this time. But Hyde recognises that this hatred stemmed from Nelly's own personal struggles and disappointments: "She had worked and sacrificed and slaved, gone hungry, gone lonely, to make us that, and we had remained soft." ${ }^{57}$ Iris and her sisters are rendered complicit in their mother's unhappiness; the children's unfulfilled potential despite their mother's efforts and sacrifice becomes part of the grounds on which Hyde apologises for Nelly's apparent hatred.

As Hyde says herself, though, these are "not the truest" memories of her mother. ${ }^{58}$ As an adult, looking back at her mother in her memoirs, fiction and poetry, she recognises her own small cruelties and her mother's resilience and strength in facing them:

Sometimes I loved her: but I liked smooth faces

Like the other mothers had, and told her so.

She laughed: she was never frightened: she took knocks

Square on the mouth, and wouldn't hit you back ${ }^{59}$

Her resilience here is demonstrated less by the interpretive statement "she was never frightened" than by her behaviour-her laughing, her taking "knocks" and the lack of retribution. The same is true of Hyde's description of Augusta's feelings. One of the key changes that Hyde made in The Godwits Fly was that she abandoned Eliza's first-person narration after the first version draft and provided a third-person narrator with limited omniscience. Despite Augusta's centrality to the novel - as well as being "the first of the godwits" she is a moral and emotional polestar for Eliza - and especially by comparison with several of the other characters, Augusta's thought processes and feelings are almost always implied, rather than described. Although Hyde has the ability to give Augusta's point of view directly because of the third-person omniscient narration that she adopts for the interim and final drafts of The Godwits Fly, she rarely allows the reader direct access to Augusta's thoughts. ${ }^{60}$ At the same time, Augusta is so carefully drawn and those things about her past and opinions that she does share aloud are so distinctive that her thoughts and feelings are as clear as if the omniscience of the narrator had not been limited in her case.

Limiting the narrator's omniscience a little also allows for moments of surprise for Eliza. In an episode that appears only in the final version, Eliza reads a poem to her mother "from an old magazine, "The Triad"':

But while I feel your kisses on my mouth,

And while your live hair clings about my hand,

I would not give this evil love of mine

For all the freedom in the world.

'Yes', said Augusta. 'Yes, that's what real love is like.' Then her right hand took up water from a china basin and shook out drops on the starched collar. ${ }^{61}$

Firmly imbedded in her habitual domestic context and occupations, Augusta comes out with something that Eliza cannot reconcile with her usual experience of her mother: "Eliza stared at her. She didn't seem at all different-red hair, worn face, square-shouldered spare body — and yet she had said that about evil love. They had never known their mother, she thought, in the positive." ${ }^{62}$ Eliza seems to feel and understand her mother's regrets, and reaches for the family story of the "Johannesburg Gentleman" in order to create a world in which Augusta might 
experience that "evil love." 63 "But suppose," Eliza thinks, "just as a dream, he had existed, still existed, and a whole intrinsic world around his face? Ah, in that world, a red-haired strong woman could drop her ironing, let the starch-water fall with a blue crash to the kitchen floor, and run and run and run...."64 This new experience of her mother "in the positive" causes Eliza to want to enable her mother to escape.

A current of regret - a longing for what might have been - lies beneath Augusta's character because it lies behind Nelly's. In marrying Eddie and having children, Nelly lost her hope, her freedom and her selfhood. In her poem "The People," Hyde recognises her mother's unspecified, underlying grief, and notes that "she never let it go." 65 The next part of the poem opens

How do I know? What a fool question! Ask

How, sick of us, she wanted back herself

Too late: or ask in what mean arid way

Was sapped her pride. I only know, one day

Her eyes weren't tired, but weak. ${ }^{66}$

Nelly stays, but "She was a cracked jug clinging to its shelf; / A fear, staring down at halfcrossed Rubicon." 67 An adult Iris remembers and understands; an adult Hyde recreates her mother's strength and sadness in beautiful, sympathetic passages such as Augusta's daydream about the house like a Greek cross. In the interim draft and final version of the novel, Augusta maintains a detailed imaginary life in England, where she has a house shaped "like a Greek cross, just outside the New Forest." "68 In her "old white house like a Greek cross [she] always had two blue vases, one very tall, one squat, for the primroses and little things." ${ }^{69}$ Late in life she finds comfort in daydreaming about "bracken, clear and brown, around the white house in England, the house like a Greek cross." "70 The dreamer is an old woman, "[b]ut it was not an old woman who lifted up her naked, enchanted face from the fern beneath the copper beech tree [...] Not an old woman, only a girl with red hair, teaching the copper beech tree its way into spring." "71 In the passages from The Godwits Fly in which Eliza imagines an escape for Augusta and where Augusta maintains and participates in her fantasy of the house like a Greek cross, Hyde testifies to the sacrifices that her mother made for her husband and children.

The understanding that Iris and Nelly came to have was not entirely retrospective. $A$ Home in this World closes with an example of Iris and Nelly and the way that they understood each other:

we had the art of saying many things, while keeping the vital ones unsaid. She looked at me, as often she does, strangely beautiful in her weary solid dignity; no pretensions. She told me the plot of a short story. "You write it. I couldn't. Besides I never get the time. Housework..." She shrugged her shoulders, shaking off housework and unwritten things. She had written, and shown me, two poems; one had been especially for me, written long ago when I was ill at Hanmer Springs. I kept it locked up in a little leather writing-case, whose gold key I eventually lost. ${ }^{72}$

Hyde wrote A Home in this World in early 1937, and left New Zealand for China and England less than a year later in January 1938. I mention this short timeframe because at the time of writing A Home in this World, Hyde states that her mother had written just the one poem for her. I found a poem among the papers at the Turnbull recently. It is impossible to date on internal evidence, but it is headed "To Iris," is written in Nelly's distinctive hand, and is initialled "N.E.W." (Nelly Edith Wilkinson).

To Iris

Weave me a rainbow from your dreams 
All radiant light and tender themes

Weave tenderly, weave tenderly

The perfect blue of children's eyes

Still sweet with thoughts of Paradise

The little wind before the dawn

The ripple of a field of corn

Weave noble thoughts to help the strong

And pitying words for sorrow's song

Weave tenderly, so tenderly

Sweet songs of birds when earth is still

The purple mists across the hill

The glory of a field of broom

The scent of gorse, and apple bloom

Weave me but these, $\&$ from the whole

A perfect rainbow, 'tis thy soul.

What do you think of my

little sermon N. E. W. ${ }^{73}$

If this is the poem that Hyde mentions at the end of A Home in this World, the poem can be dated to the period March-October 1927, the time of Iris' stay at Hanmer Springs. Unless Nelly wrote another poem for Iris in the nine months between Iris' writing A Home in this World and her leaving New Zealand, it seems that someone found the key to the leather writing case.

Below all of these versions of the relationship between a mother and a child lies, simultaneously, a conflict of values and a deep understanding that does not need the intervention of an omniscient narrator to make itself clear. Hyde creates a version of her mother that is not reliant on an artificial, literary access to another person's thoughts; most of the time, Augusta's "steady hand and steady heart" can speak for itself. ${ }^{74}$ Released from the "autobiographical pact," Hyde is able to build a carefully nuanced, sympathetic and emotionally accurate version of her mother and of her own relationship with her mother. The sympathetic elements and key autobiographical details that go into creating this version of her mother, particularly in the later drafts of the novel, are important also to other versions of Nelly that Hyde created, such as the one found in "The People." Although Augusta's literary function, strictly speaking, might be to represent an aspect of Eliza's struggle for a sense of identity, and although she might not be exactly Nelly, one might say that by exercising the privileges of the author on this version of her mother, she is also more exactly Nelly for Iris than a strictly "factual" version of Nelly herself could have been. 
${ }^{1}$ Quotation is taken from Hyde's inscription on the copy she sent to Dr Gilbert Tothill:

Dr G. M. Tothill

This imperfect part of truth

Robyn Hyde (Iris Wilkinson)

April 1939, England

See the Introduction to Sandbrook's edition of The Godwits Fly (Auckland: Auckland University

Press, 2001), ix. All references to and quotations from the final, published version of the text are taken from Sandbrook's edition.

${ }^{2}$ As much as possible, I have tried to use "Robin Hyde" to refer to Iris Wilkinson in her authorial persona. This distinction is sometimes difficult, and may seem artificial, but is important for a paper where a life that was lived is being compared with its fictionalised equivalent and the process of achieving that end.

${ }^{3}$ Letter from Iris Wilkinson to John A. Lee, 2 April, 1937, Lee Collection, Auckland Public Library (quoted in Patrick Sandbrook, "Robin Hyde: A Writer at Work," (Ph.D. thesis, Massey University, 1985), 13).

${ }^{4}$ Mary Edmond-Paul, Your Unselfish Kindness: Robin Hyde's Autobiographical Writings (Dunedin: Otago University Press, 2011), 217.

${ }^{5}$ See Sandbrook's introduction to The Godwits Fly, pp. xvii-xxii, for an account of Hyde's work on the novel and the conditions under which it was produced.

${ }^{6}$ Letter from Iris Wilkinson to John A. Lee, 9 November, 1938 (cited in Gillian Boddy and Jacqueline Matthews, Disputed Ground: Robin Hyde, Journalist (Wellington: Victoria University Press, 1991), 6).

${ }^{7}$ Bruner goes on to explain further that autobiography "is a way of construing experience - and of reconstructing and reconstruing until our breath or our pen fails us. Construal and reconstrual are interpretative. Like all forms of interpretation, how we construe our lives is subject to our intentions, to the interpretive conventions available to us, and to the meanings imposed upon us by the usages of our culture and language" (Jerome Bruner, "The Autobiographical Process," in The Culture of Autobiography: Constructions of Self-Representation, ed. Robert Folkenflik (Stanford: Stanford University Press, 1993), 38).

${ }^{8}$ Mary Edmond-Paul has edited this autobiography from the manuscript held in the Sir George Grey Collection, Auckland Public Library, as part of Your Unselfish Kindness.

${ }^{9}$ Snippets of life in the hospital appear throughout the autobiography. Near the beginning of chapter eight, for example, Hyde writes "And I'm inclined to think the others are as bad, or worse.

Somebody's had fourpence filched from her locker, or believes that she has. Dramatic discussion on the verandah! (Oh, oh, if you'd only give me sound proof windows, or the sort of cell affected by the dirtiest of Tibetan saints!)" (Edmond-Paul, Your Unselfish Kindness, 90). Hyde comments regularly on the process of constructing the autobiography, often in combination with comments about Tothill's requirements or what he has said or will think. Chapter four opens with "Oh dear! As usual, reading over a page and a paragraph of this, I wonder if I should have cut it down to half a dozen facts, naked as they came into the world. But how can I? Incident means little or nothing, except a possibly neglected chance for a new perception, a new development. I've left out hundreds of millions of things, so that you shan't be quite overwhelmed by bindweed in these childish paths" (Edmond-Paul, Your Unselfish Kindness, 73).

${ }^{10}$ Letter from Iris Wilkinson to J. H. E Schroder (Letter 74), 29 July, 1934, Alexander Turnbull Library, MS-Papers-0280-05, 3.

${ }^{11}$ Letter from Iris Wilkinson to J. H. E. Schroder (Letter 75), [?August] 1934 Alexander Turnbull Library, MS-Papers-0280-06, 7.

${ }^{12}$ Sandbrook, "Robin Hyde," 13.

${ }^{13}$ Sandbrook, "Robin Hyde," 104; original emphasis.

${ }^{14}$ Anna Rutherford, "Lee, John (Alexander)," in $20^{\text {th }}$ Century Fiction, ed. George Woodcock (London and Basingstoke: Macmillan, 1983), 373-75; quotation from 374. 
${ }^{15}$ Alison Hunt notes that drowning was not a typical way for a woman to attempt suicide, tending to prefer more private methods, such as household poison (" "The Cage with the Open Door':

Autobiography and Psychiatry in the Life and Works of Robin Hyde" (Ph.D. thesis, University of Auckland, 2008), 22, n. 8). In an April 1936 letter to Lee, Wilkinson says that she "shan't write about the last three years until I am 'good and dead," suggesting that she was aware that her circumstances, if they were known, might cause her problems during her lifetime (Letter to John A. Lee, 21 April 1936, quoted in Derek Challis and Gloria Rawlinson, The Book of Iris (Auckland: Auckland University Press, 2002), 333.)

${ }^{16}$ Sandbrook, "Robin Hyde," 351. Shelfmarks for all of the draft material—in both the Turnbull and University of Auckland collections - have been updated to reflect their current locations and descriptors.

${ }^{17}$ Sandbrook, "Robin Hyde," 4.

${ }^{18}$ Sandbrook, "Robin Hyde," $187 \mathrm{ff}$.

${ }^{19}$ Sandbrook, "Robin Hyde," 133-35.

${ }^{20}$ The "autobiographical pact" is an understanding between reader and author suggested by Philippe Lejeune; it is based upon his definition of autobiography as a "Retrospective prose narrative written by a real person concerning his own existence, where the focus is his individual life, in particular the story of his own identity," and specifically upon the identity of name between author, narrator and the protagonist whose life is being described. (Philippe Lejeune, On Autobiography, ed. Paul John Eakin, trans. Katherine Leary, Theory and History of Literature 52 (Minneapolis: University of Minnesota Press, 1989), 4, 12).

${ }^{21}$ The Godwits Fly, xxxiii.

${ }^{22}$ Edmond-Paul, Your Unselfish Kindness, 68.

${ }^{23}$ Robin Hyde, "The Godwits Fly," Unpublished Draft, Alexander Turnbull Library, MS-Group 1648, MS-Papers-9110-135, 21. (Hereafter referred to as "First Version Draft").

${ }^{24}$ First Version Draft, 17.

${ }^{25}$ First Version Draft, 22. Augusta-the-war-widow is certainly not the only marginalised, struggling woman trapped by circumstance in the first draft. Particularly towards the end of the novel, several others emerge: Mrs McPhee, Billy's mother; Hildred, Eliza's companion and unwed mother of a nowadult, jailed son; and the unnamed old woman Eliza escorts home, and who removes the stale bread, orange skins and dead (possibly poisoned) pigeon that she has collected during the day and stowed in pockets in her petticoats in order to supplement her diet, all as Eliza watches. Mrs McPhee's and Hildred's stories in chapter thirteen and the story of the old lady in chapter fourteen are separated by a long description of New Zealand society in boom and bust - exactly the sort of political diatribe that Rawlinson criticises when she says that the action of the first version "is becalmed by long dissertations on New Zealand customs, social, sexual, and political, interesting as journalism but deadly to the pace of narrative" (quoted in Sandbrook, "Robin Hyde," 20). Hyde excises these passages in redrafting the novel, and Mrs McPhee, Hildred and the old lady with them, but her concern for social issues and particularly the social issues of women do not disappear. For an account of how Hyde addresses these concerns in the final version of The Godwits Fly and some of her other writings, see Mary Paul, Her Side of the Story: Readings of Mander, Mansfield \& Hyde (Dunedin: University of Otago Press, 1999), particularly 162-78.

${ }^{26}$ The Godwits Fly, 45.

${ }^{27}$ Notes on Admission, 20 June, 1933, Alexander Turnbull Library, MS-Group-1648, MS-Papers9110-149.

${ }^{28}$ Edmond-Paul, Your Unselfish Kindness, 74.

${ }^{29}$ The Godwits Fly, 17. It is in Newtown that John "caught rheumatism, bibliomania and politics, none of which he could afford" (The Godwits Fly, 18).

${ }^{30}$ The Godwits Fly, 18.

${ }^{31}$ Letter quoted in Book of Iris, 7.

${ }^{32}$ Robin Hyde, "The People" II, lines 4-10, Young Knowledge: The Poems of Robin Hyde, ed. Michele Leggott (Auckland: Auckland University Press, 2003), 381. Nelly's sewing machine features again in a letter that Iris sent home to her mother from China about the poems that were collected and edited, posthumously, as Houses by the Sea (the collection that includes "The People"). Iris writes, 
"The last poems I've been writing (not very good, and very incomplete) are a longish series about Wellington, from Island Bay to your sewing-machine" (quoted in Book of Iris 616, and Young

Knowledge 29).

${ }^{33}$ The Godwits Fly, 178.

${ }^{34}$ The Godwits Fly, 84.

${ }^{35}$ The Godwits Fly, 27-28.

${ }^{36}$ The Godwits Fly, 22-23.

${ }^{37}$ The Godwits Fly, 38-39.

${ }^{38}$ See, for example, The Godwits Fly, 24-25.

${ }^{39}$ Kitch's real-life equivalent is Ruth; after the first version draft, in which "the war baby" is a little girl named Louvain, Hyde provides a male equivalent for her youngest sister.

${ }^{40}$ First Version Draft, 79.

${ }^{41}$ Edmond-Paul, Your Unselfish Kindness, 111.

${ }^{42}$ Edmond-Paul, Your Unselfish Kindness, 111 (Original emphasis). It seems that matrimony may have been the way that Nelly and Eddie solved an unplanned pregnancy themselves; The Book of Iris notes that they were married on 6 April 1903, and that Hazel, their first daughter, was born fewer than five months later (Book of Iris, 5).

${ }^{43}$ Book of Iris, 77. As Alison Hunt explains, given the uncertain date of baby Robin's death, it is possible that Nelly was with Iris before Robin died. Nelly travelled to Sydney on 16 September, and returned to New Zealand with Iris on 30 November; there are few other certainties regarding the context of Nelly's trip (Hunt, "Cage with the Open Door," 20-21).

${ }^{44}$ The Godwits Fly, 196.

${ }^{45}$ First Version Draft, 160.

${ }^{46}$ First Version Draft, 160, 162.

${ }^{47}$ First Version Draft, 162-63.

${ }^{48}$ First Version Draft, 162.

${ }^{49}$ Edmond-Paul, Your Unselfish Kindness, 118-121.

${ }^{50}$ The accounts of this incident in the published version of The Godwits Fly and in the 1934

Autobiography suggest a desire to die, or at the very least a carelessness about living. In The Godwits Fly, Eliza takes a large quantity of drugs before boarding a train, planning to "stand on one of the little black jolting platforms. When the train curled round the first rough bend, your drugged body would be jolted off, and everybody would say, 'How sad-an accident'. But she took the powders too soon" (The Godwits Fly, 215). In the 1934 Autobiography she says that she takes "Eleven grains of luminol, ten of veronal, and (bathos!) some aspirin, all together. And I woke up!" (Edmond-Paul, Your Unselfish Kindness, 120). Hunt's analysis makes Iris's hospitalisation seem more accidental-merely the result of "continuing the drug-taking begun at Rotorua" (Hunt, "Cage with the Open Door," 16).

${ }^{51}$ The Godwits Fly, 217.

${ }^{52}$ The Godwits Fly, 217.

${ }^{53}$ Robin Hyde, A Home in this World, ed. Derek Challis (Auckland: Longman Paul, 1984), 65.

${ }^{54}$ Hyde, A Home in this World, 65.

${ }^{55}$ Hyde, A Home in this World, 65.

${ }^{56}$ Hyde, A Home in this World, 73-74.

${ }^{57}$ Hyde, A Home in this World, 74.

${ }^{58}$ Edmond-Paul, Your Unselfish Kindness, 111.

${ }^{59}$ Hyde, "The People" II, lines 13-16, Young Knowledge, 381.

${ }^{60}$ In the interim drafts and final version of the novel, the narrative is centred, for the most part, on Eliza Hannay and her impressions, but the change in narrative point of view allows the narrator to follow the actions and musings of other characters, sometimes for a full chapter at a time. Carly, Eliza's sister gets almost a whole chapter to herself, as does John. Timothy Cardew, Eliza's first love, gets two whole chapters and large sections of several others.

${ }^{61}$ The Godwits Fly, 84.

${ }^{62}$ The Godwits Fly, 84.

${ }^{63}$ The "Johannesburg Gentleman" (the "Perth Gentleman" in the interim drafts) is the subject of a mythical relationship that John created around Augusta, but to which Carly attached herself as an 
alternative true father, a father who was better aligned with her values and social ambitions than was John.

${ }^{64}$ The Godwits Fly, 84.

${ }^{65}$ Hyde, "The People" II, line 18, Young Knowledge, 381.

${ }^{66}$ Hyde, "The People" III, lines 1-5, Young Knowledge, 381.

${ }^{67}$ Hyde, "The People" III, lines 13-14, Young Knowledge, 382.

${ }^{68}$ The Godwits Fly, 101.

${ }^{69}$ The Godwits Fly, 119. The house like a Greek cross is emblematic of Augusta's attachment to England. In an episode that Sandbrook calls "epiphanic" ("Robin Hyde," 217), Augusta realises that her life had only been half lived because the richest part of her life - her imaginary life — had been deferred and dislocated elsewhere. She had not accepted the reality of her location, symbolised by the grey New Zealand hills, and she wishes, too late, that she "had tramped round their edges years ago, instead of huddling into the auction sales" (The Godwits Fly, 179). The grey New Zealand hills are set in opposition to "the white house [that] stood empty somewhere, the little clenched fists of bracken thrusting up beside its paths, its windows like golden blinded eyes" (The Godwits Fly, 178). She is able to return to the comfort of her daydreaming later in the novel, however, and the white house is restored to its former beauty and wholeness.

${ }^{70}$ The Godwits Fly, 222.

${ }^{71}$ The Godwits Fly, 223.

${ }^{72}$ Hyde, A Home in this World, 101.

${ }^{73}$ Alexander Turnbull Library, MS-Group-1648, Inward Correspondence, MS-Papers-9110-212.

${ }^{74}$ First Version Draft, 162. 